第 6 就 ヨウ装吸着法によるアクセシビリテイーの測定

\begin{tabular}{|c|c|c|}
\hline 武 ${ }^{\circ}$ 料 & ヨウ秦吸肖量 $(\mathrm{mg} / \mathrm{g})$ & アクセシビリティー（\%) \\
\hline 䄸 & 43.4 & 11 \\
\hline BXファイバ- & 118.9 & 29 \\
\hline 絹 & 173.9 & 43 \\
\hline 超強力人絹 & 187.4 & 46 \\
\hline 対 殹 試 料 & 234.4 & 58 \\
\hline 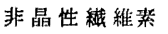 & 404.8 & 100 \\
\hline × & 405.8 & 100 \\
\hline
\end{tabular}

（7）アルカリ溶解度 カセイソーダ水溶液に対する㵶維素の 溶解性は，その重合度ならびに結晶性に依存することはよく知ら れている。非晶性繊維素の溶解度は第 7 表に示すよ 5 に比較試料 にくらべて著しく大である。

第 7 表 カセイソーダ溶液に対する溶解度

\begin{tabular}{|c|c|c|c|}
\hline \multirow[b]{2}{*}{ 就 } & \multicolumn{3}{|c|}{ カセイソーダ灌度 } \\
\hline & $\underset{(\%)}{1 \% \underset{(N a H}{\mathrm{NaOH}}}$ & $5 \% \underset{(\%)}{\mathrm{NaOH}}$ & $\begin{array}{c}10 \% \underset{\mathrm{NaOH}}{(\%)} \\
\end{array}$ \\
\hline 棉 & 0.54 & 1.72 & 2.03 \\
\hline BXファイバー & こん跡 & 0.31 & 5.86 \\
\hline 人 & こ几跡 & 3.01 & 29.37 \\
\hline 超強力人絹 & こん跡 & 1.31 & 34.98 \\
\hline 対照試 料 & こん跡 & 3.47 & 35.01 \\
\hline 非晶性䉽維縈 & 1.32 & 79.03 & 80.48 \\
\hline
\end{tabular}

重合度の高く，結晶性のすぐれた木綿にくらべて，非晶性緎維 素が溶解度の大きいことは当然であるが，重合度がほぼ等しい人 給に比較しても，著しく溶解度が大きく，またカセイソーダ濃度 を普通再生䋐維素の最大のミセル内膨潤を起させると考文られて いる $10 \%$ にまで上昇しても，この溶解度が $5 \%$ 溶液の場合とほ とんど变わらないことは, 非晶性緘維素の非晶性を十分示唆する

第 8 表 各種の方法によって测定した結晶度（\%）

\begin{tabular}{|c|c|c|c|c|c|c|}
\hline 試 料 测定法 & $\mathrm{X}$ 線 & $\begin{array}{l}\text { 水 分 } \\
\text { 収 着 }\end{array}$ & 密度 & $\begin{array}{l}\text { 酸加水 } \\
\text { 分 解 }\end{array}$ & キ酸化 & $\begin{array}{l}\text { 资ウ秦 } \\
\text { 吸意 }\end{array}$ \\
\hline 粕 & - & 67 & 53 & 96 & 79 & 89 \\
\hline $\mathrm{BX}$ ファイバー & - & 62 & - & 86 & 58 & 71 \\
\hline 䊘 & 37 & 43 & 36 & 81 & 42 & 57 \\
\hline 超強力人絹 & - & 36 & - & 74 & 21 & 54 \\
\hline 対照 武 料 & 25 & 29 & - & 76 & 38 & 42 \\
\hline 非晶性 䋞䧽素 & 7 & 10 & 0 & 10以下 & $=10$ & 0 \\
\hline
\end{tabular}

あのである。

（8）非晶性繊維素の結晶構造 上述のような各種の方法によ り測定した結晶度を総括して示すと第 8 表のと扣りである。

木綿, BX ファイバー, 人綟, 超強力人絹, 対照試料について の各測定值は, 類似試料についての他の研究者の結果とよく一致 している。

われわれは㵶維素が内部構造的に, 結晶, 無定形の 2 成分より なるとの仮定のもとに，結晶度の測定を行ってきた。しかしなが ら，現在の緘維素の超分子構造の概念にしたがえば，䋊維素の内 部構造を結晶, 無定形の 2 成分に明確に区分することは危険であ り, むしろこの両者を両端とするラテラルオーダ一の連続的分布 を考えるのが妥当である。したがって Howsmon ${ }^{16)}$ が図をあげて 説明しているょうに，いわゆる結晶度の絶対値はその測定法，す なわちいかなるラテラルオーダーをもって結晶と無定形の区分点 とみなすかによって当然相違するはずである。しかるに，われわ れのえた非晶性㵶維素が第 8 表に示すよ5に，湘定法の相違，す なわち結晶と無定形の区分点の相違にかかわらず，常に結晶度 0 〜10\%の值をえていることは，緘維素物質の $90 \%$ 以上が非常に ラテラルオーダーの低い組織よりなりたっていることを示するの である。さらに第 8 表に扔いて非晶性䋐維素と対照試料の結晶度 が明確に異なっている点より考えると，この 2 種の試料の調製法 の相違点はビスコースへのジメチルアミン添加の有無のみである から, ジメチルアミンの特異な機能によって, 再生㵶維素が著し く非晶化されると推断される。

（昭和 33 年 4 月，日化第 11 年会講演）

終りに本実験にあたり試料のX線に関する測定を行って頂いた 京都大学工学部繊維化学教室温品恭彦氏ならびに種々御指導をい たたいた当社高松勇治郎常務取締役，野田清之助取締役に深謝し ます。

16) R.H. Morchessault, J.A. Howsmon, Textile Research J. 27, 30 (1957).

\title{
ジベンジルエーテルと無水フタル酸をたは無水マレイン酸との反応 およびマレイン酸ジベンジルとスチレンとの共重合†
}

（昭 和 33 年 1 月 30 日 理 受)

\section{桜井 富士男・黄慶 雲*}

\begin{abstract}
ジベンジルェーテルと無水フタル酸または無水マレイン酸とを酸触媒で反応せしめ，それぞれフタル酸ジベンジルまた はマレイン酸ジベンジルの生成することを確認した。同時に無水フタル酸との反応の場合に $-\left[-\mathrm{C}_{6} \mathrm{H}_{4} \cdot \mathrm{CH}_{2}-\right]-n$ なる樹脂 が副生することも知った。また無水マレイン酸との反応の活性化熱として，17.3 kcal $/ \mathrm{mol}$ を得た。このよ5にして製造 したマレイン酸ジベンジルとスチレンとを共重合せしめ, $70^{\circ} \mathrm{C}$ に打笚量体の反応性比 $r_{1}\left(\right.$ スレン) $=0.55 \pm 0.2, r_{2}$ (マレイン酸ジベンジル) $=0.02 \pm 0.01$ を得た。
\end{abstract}

緒言

Wegler ら ${ }^{1)}$ はキンンンルムアルデヒド樹脂と二塩基性酸無

$\dagger$ 本報を「ホルムアルテヒド系樹脂に関する研究（第 46 報）」 とする. 前報, 井本, 大岩, 黄, 工化 61，1646 (1958).

* 大阪市立大学理工学部：大阪市北区南扇町.

1) R. Wegler, K. Faber, Angew. Chem. 60, 80 (1948).
水物とが（1）式に示すような反応で硬化しうることを述べてい る。

著者らはこのような反応を確実にする目的で，ジベンジルェー テルと無水フタル酸または無水マレイン酸との反応を研究した。 もし（1）式の反応が起るならば，マレイン酸との反応生成物は 二重結合を残存しているから，共重合性についての研究は不飽和 
<smiles>Cc1ccc(COCOCc2ccc(C)cc2C)cc1</smiles><smiles>Cc1ccc(COC(=O)COC(=O)c2ccc(C)cc2C)c(C)c1</smiles>

ポリエステル樹脂の硬化反応とも関連して興味深いとであるの でスチレンとの共重合反応についても実験を行った。

\section{実 験と結 果}

\section{（1） ジベンジルエーテルと無水フタル酸之の反応}

ジベンジルェーテル (bp $130^{\circ} \mathrm{C} / 4 \mathrm{mmHg}, d_{4}^{25}=1.036, n_{\mathrm{D}}^{25}=$ $1.558)$ を $39.6 \mathrm{~g}(0.2 \mathrm{~mol})$, 無水フタル酸 $14.8 \mathrm{~g}(0.1 \mathrm{~mol})$ 打 よび触媒としてリン酸 $4.0 \mathrm{~g}$ を封管中にとり， $180^{\circ} \mathrm{C}$ およぴ 220 ${ }^{\circ} \mathrm{C}$ でそれぞれ 20 時間反応せしめた。反応物を酻酸エチルに溶解 し, 炭酸ソーダ水溶液 $(10 \%)$, つづいて水で洗浄し，ボウ硝で 乾燥後减圧蒸留して, bp $205 \sim 206^{\circ} \mathrm{C} / 10^{-2} \mathrm{mmHg}$ の留分を得た。 これをベンゼンに溶解し，メタノールで再沈殷せしめる操作を数 回くり返して精製した。この特性は第 1 表は示すようにフタル酸 ジベンジルの理論值とよく一致する。

第 1 表 フタル酸ジベンジル

\begin{tabular}{|c|c|c|c|c|c|c|}
\hline $\begin{array}{c}\text { 反応温度 } \\
\left({ }^{\circ} \mathbf{C}\right)\end{array}$ & $\begin{array}{l}\text { 坚量 } \\
\text { (g) }\end{array}$ & $\begin{array}{l}\text { 译率 } \\
(\%)\end{array}$ & 点 & 融。点 & 分子最 ${ }^{a)}$ & $\begin{array}{l}\text { エステ } \\
\text { ル価 }\end{array}$ \\
\hline S 180 & 20.1 & 6.1 & $205 \sim 206^{\circ} \mathrm{C} / 10^{-2} \mathrm{mmHg}$ & $38 \sim 39$ & 350 & 334 \\
\hline 2220 & 3.2 & 9.2 & $205 \sim 206^{\circ} \mathrm{C} / 10^{-2} \mathrm{mmHg}$ & $38 \sim 39$ & 350 & 332 \\
\hline 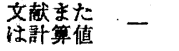 & - & - & $\left.275^{\circ} \mathrm{C} / 12 \mathrm{mmHg}^{2}\right)$ & $\left.41 \sim 42^{2}\right)$ & 346 & 324 \\
\hline
\end{tabular}

a) ペンゼンを用いる氷点降下法

なお，茶褐色の樹脂状物が，蒸留残留物として残るが， $220^{\circ} \mathrm{C}$ で反応を行った時の蒸留残留物は $15.8 \mathrm{~g}$ 得られ, $\mathrm{mp} 51 \sim 55^{\circ} \mathrm{C}$, 分子量（ベンゼン氷点降下法） 1100 , 元素分析值 C : $93.02 \%$, $\mathrm{H}: 6.33 \%, \mathrm{C}_{7} \mathrm{H}_{6}$ としての計算値 'C : $93.33 \%, \mathrm{H}: 6.67 \%$ 。 これは（2）式で示すような反応で生成すると考えられる。

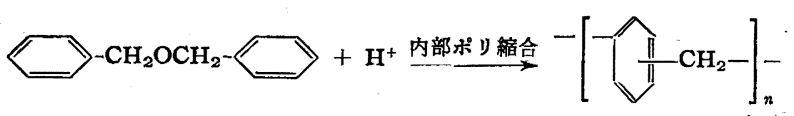

（2） ジヘンジルエーテルと無水マレイン酸との反応

温度計, 還流冷却器およびカキマゼ機を付した三つロフラスコ にジベンジルェーテル $51.5 \mathrm{~g}(0.26 \mathrm{~mol})$, 無水マレイン酸 $25.6 \mathrm{~g}$ (0.26 mol) および触媒として $m$ 拉ンンンスルホン酸 $0.307 \mathrm{~g}$ $(0.0017 \mathrm{~mol})$ をとり, $96^{\circ} \mathrm{C} て ゙ 20$ 時間反応を行った。反応物を 実験（1）と同様に処理し, 減圧蒸留により bp $163^{\circ} \mathrm{C} / 10^{-2} \mathrm{mmHg}$ の留分 $14.6 \mathrm{~g}$ (収率 $18.8 \%$ ) を得た。この特性を第 2 表に示す が, マレイン酸ジペンジルとよく一致している。

第 2 表 マレイン酸ジベンジル

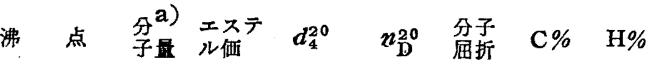

\begin{tabular}{llllllll}
\hline 实雅值 $163^{\circ} / 10^{-2} \mathrm{mmHg}$ & 290 & 379 & 1.165 & 1.5797 & 84.53 & 72.27 & 5.49
\end{tabular}

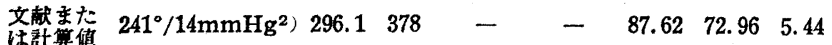

a) ベンゼン氷点降下法

つぎに無水マレイン酸との反応速度を測定するために，ジベン ジルェーテル $51.5 \mathrm{~g}(0.26 \mathrm{~mol})$, 無水マレイン酸 $25.6 \mathrm{~g}(0.26$

2) T.J. Thompson, G. J. Leuck, J.Am. Chem. Soc. 44, 2894 (1922). mol）㧍よび触媒として m-キシレンスルホン婹 $0.307 \mathrm{~g}(0.0017$ $\mathrm{mol}$ )を還流冷却器，温度計执よびカキマゼ㙨を什した三つ口フ

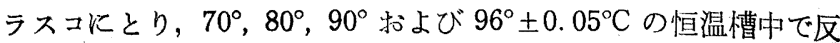
応させ，無水マレイン酸の減少量を追跡した。反応浴中が均一と なったと考えられる 5 分後から測定を開始し, 所定時間ごとに試 料をとり，精科し，これに約 $50 \mathrm{cc}$ のェタノールを加えてフェノ ールフタレンを指示薂として $0.5 \mathrm{~N}$ アルコール性カセイカリ溶 液で酸価を測定し, 酸価の減少量から反応率を計算した。第 1 戍 に各温度における反応率と時間との関係を示す。これらの測定温 度から求めた活性化熱は $17.3 \mathrm{kcal} / \mathrm{mol}$ であった。

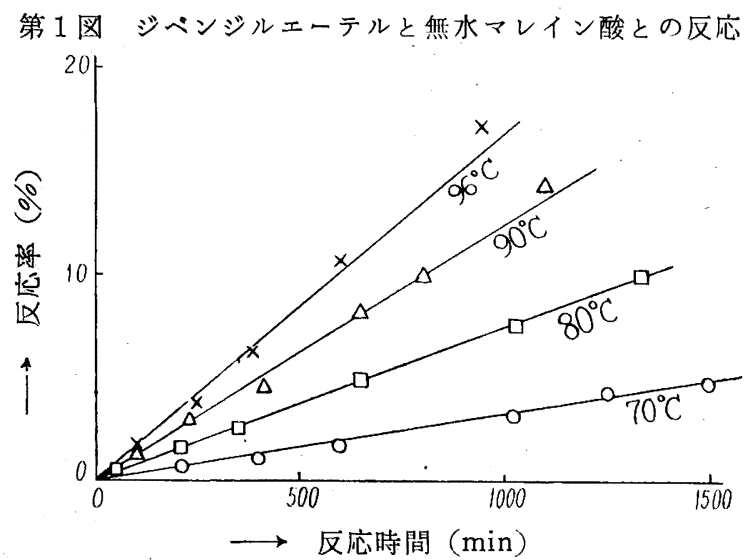

（3） マレイン酸ジベンジルとスチレンとの共重合

マレイン酸ジベンジルとスチレンとの合計が $0.1485 \mathrm{~mol} / l$ の 濃度になるようにして，両者の比を種々変化させたベンゼン溶液 $15 \mathrm{cc}$ と過酸化ベンゾイル $0.02 \mathrm{~g}$ を封管にとり，窒素置換後減 庄で封じ, $70 \pm 0.1^{\circ} \mathrm{C} て ゙ 2.5$ 時間らりまぜつつ重合を行った。こ の時の重合率は 4 7\% であった。重合物の元素分析値から共重 合体中の単量体組成を算出し，この值を Mayo-Lewis 式に適用 し, $70^{\circ} \mathrm{C}$ に打ける単量体の反応性比 $r_{1}$ (スチレン), $r_{2}$ (マレイ ン酸ジベンジル）を求めた。

$$
\begin{aligned}
& r_{1}=0.55 \pm 0.1 \\
& r_{2}=0.02 \pm 0.01
\end{aligned}
$$

第 2 図単量体一共重合体組成曲線掞よび其重介休組成一 極限粘度の関係

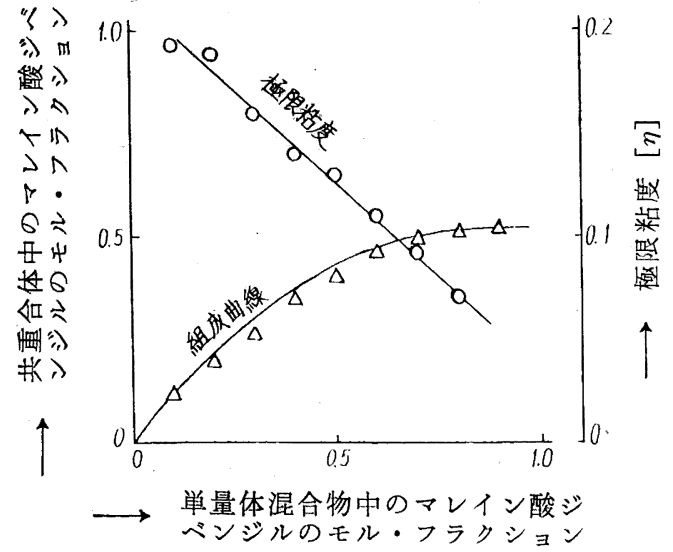

第 2 図に単量体・共重合体組成曲線および極限粘度を示す。極 限粘度は Ostwald 粘度計を用い， ベンゼン溶液中 $30 \pm 0.01^{\circ} \mathrm{C}$ で測定した。極限粘度执よび反応率はスチレン・モノマー量の增 加にともなって増大する傾向が認められた。

本実験を御指導下さった井本 稔教授に深く感謝少る。 